\title{
Profiling the participants in creative tourism activities: Case studies from small and medium sized cities and rural areas from Continental Portugal
}

\author{
Paula Remoaldo $^{\mathrm{a}, *}$, Jaime Serra ${ }^{\mathrm{b}}$, Noémi Marujo ${ }^{\mathrm{b}}$, Juliana Alves ${ }^{\mathrm{a}}$, Alexandra Gonçalves ${ }^{\mathrm{c}}$, \\ Sónia Cabeça ${ }^{\mathrm{c}}$, Nancy Duxbury ${ }^{\mathrm{d}}$
}

${ }^{a}$ Lab2PT-Landscape, Heritage and Territory Laboratory, University of Minho, Portugal

${ }^{\mathrm{b}}$ CIDEHUS-Interdisciplinary Centre for History, Culture and Societies, University of Évora, Portugal

${ }^{\mathrm{c}}$ CinTurs-Research Centre for Tourism, Sustainability and Well-being, University of Algarve, Portugal

${ }^{\mathrm{d}}$ CES-Centre for Social Studies, University of Coimbra, Portugal

\section{A R T I C L E I N F O}

\section{Keywords:}

Creative tourists

Creative tourism

Cluster analysis

Rural areas

Portugal

\begin{abstract}
A B S T R A C T
Although cultural tourists increasingly seek to experience cultural events actively and to directly engage in creative activities, empirical knowledge about the creative tourist remains limited. This study aims to characterize the motivations and profile of creative tourists. The data was collected through a survey of participants in creative tourism activities in Portugal developed by 40 pilot institutions of the CREATOUR project during 2017 and 2018, with 814 usable questionnaires collected and validated. The questionnaire had 30 questions and marked the first time this kind of research was conducted in Portugal. The questionnaire included questions on: the composition of their travel companions, their previous participation in a creative tourism experience, reasons for visiting the destination, their characterization of the creative tourism experience, an evaluation of their creative tourism experience, and their socio-demographic profile. Using a cluster analysis to analyse the data, three clusters were found: Novelty-Seekers, Knowledge and Skills Learners, and Leisure Creative-Seekers.
\end{abstract}

\section{Introduction}

In the 1980s, Alvin Toffler (1980) pioneered the concept of "prosumer" to refer to a type of consumer involved in product design and in production itself. With the diffusion of the concept of prosumer - a fusion of the words "producer" and "consumer" - since that time, the consumer has become the producer of many of the products and experiences he consumes. The diffusion of this concept coincides with the emergence of a new generation of tourists, also called "qualified consumers" or "creative consumers" (Carvalho, Ferreira, \& Figueira, 2016; Mihajlović \& Koncul, 2016; Pappalepore, Maitland, \& Smith, 2014; Richards, 2010a; Richards \& Wilson, 2006; Zhang \& Yu, 2018), postmodern travellers (Carvalho et al., 2016; Jelinčić \& Žuvela, 2012; O’Dell, 2007; Pappalepore et al., 2014; Tan, Luh, \& Kung, 2014) or “creative tourists" (Raymond, 2003; Smith, 2016; Tan et al., 2014; Zhang \& Yu, 2018).

Regardless of the term applied, they all refer to tourists who actively create their experience in the destinations they choose. This new consumer of experiences has played an increasingly active role in the economy, leaving aside the passivity characteristic of the 1980s, to play an essential role in market communication (Egger, Gula, \& Walcher, 2016; Kotler, Kartajaya, Setiawan, \& Vandercammen, 2012; Tan et al., 2014; Zhang \& Yu, 2018).

For Alvin Toffler (1980), the concept of prosumer defines a type of consumer of the future, involved in the design and production of products to make them more personalized and individualized. In addition, prosumers are more informed, more educated and with an aboveaverage level of demand. In this sense, the creative tourist can be seen as a prototype of the prosumer (Fundação de Serralves, 2008; Tan et al., 2014; Egger et al., 2016; Zhang \& Yu, 2018).

There is a great diversity of definitions of creative tourists, ranging from those that refer to participants in dance art experiences or handicraft workshops, to those that include people temporarily residing in artistic residences in search of creativity. According to Richards (2011), creativity can be used to implement creative tourism as a tourist activity, which involves the active involvement of tourists in the creative activities of the places they visit, or as a backdrop for tourism, in which tourists place themselves in a chosen creative environment.

Nevertheless, despite these efforts, defining the concept of creative tourism and describing the motivations and profiles of those who

\footnotetext{
* Corresponding author at: Lab2PT-Landscape, Heritage and Territory Laboratory, University of Minho, 4710-057 Braga, Portugal.

E-mail addresses: premoaldo@geografia.uminho.pt (P. Remoaldo), jserra@uevora.pt (J. Serra), noemi@uevora.pt (N. Marujo), marodrig@ualg.pt (A. Gonçalves), duxbury@ces.uc.pt (N. Duxbury).
} 
engage in creative activities during their holidays are not easy tasks. The term "creative tourism" is relatively young and began to draw attention in the scientific milieu in the 1990s. Pearce and Butler (1993) were the first to mention creative tourism as a potential form of tourism. The definition most used by the experts in this area is the one elaborated by Richards and Raymond (2000), who define creative tourism as offering tourists the opportunity to develop their creative potential through active participation in courses and learning experiences that are the characteristics of the destination in which they are carried out.

Over the last two decades, tourist demand has become increasingly exacting, segmented and constantly changing (Fundação de Serralves, 2008; Tan et al., 2014; Carvalho et al., 2016; Smith, 2016; Zhang \& Yu, 2018). This process points to the emergence of a new tourist profile and, consequently, a new pattern of consumption that is directed toward the use of creativity as an alternative to mass cultural tourism. Creative tourists are not satisfied to only observe cultural events and passively visit cultural spaces, but seek to experience them actively. They seek memorable events (Pine \& Gilmore, 1999) and usefulness rather than novelty (Tan, Kun, \& Luh, 2013). There are mindful visitors (Moscardo, 1996) who want to become a part of the destination's everyday dynamics (Ilincic, 2014) and ask for active participation and greater involvement with the local community (Carvalho et al., 2016; Mihajlović \& Koncul, 2016; Ohridska-Olson \& Ivanov, 2010; Richards, 2003; Richards \& Raymond, 2000; Richards \& Wilson, 2007; Smith, 2016; Zhang \& Yu, 2018).

Generally, creativity is associated with urban areas, especially large cities. This relationship between creativity and the city derives from the fact that creative industries have been greatly responsible for dynamizing the attractiveness of the cities, making them more attractive for companies, for new inhabitants and, consequently, for tourists (Argent, Tonts, Jones, \& Holmes, 2013; Boes, Buhalis, \& Inversini, 2015; Dekker \& Tabbers, 2012; Richards, 2011; Richards, 2014a).

This new type of tourist results from the depleted model of massified cultural tourism which does not gives him/her opportunities to have an active role. This depleted model can be clearly observed in Southern Europe countries that have been suffering from a high pressure of visitors in recent decades. In Portugal (the territory analysed in the present paper) massified cultural tourism began to occur in recent years, especially in large cities like Lisbon and Porto. Creative tourism appears as an opportunity to reinvent the current tourism model and offer a form of tourism that is more sustainable and close to the local community.

The profile of cultural tourism is well defined and supported by a long spectrum of scientific research, but little is known about the creative tourist. The few international studies dedicated to the profile of the creative tourist continue to highlight the complexity of this segment, which involves tourists from multiple generations (children, adults and the elderly) looking for authenticity, exclusivity, improving skills and desiring contact with the local community. Noting that these insights are derived from a generalized international level, the profile of the creative tourist has not been clearly characterized in Portugal, especially the one that visits small and medium-sized cities and rural areas. In the research presented in this article, we specifically analyse the profile of this kind of visitor. We studied the tourists who participated in creative tourism experiences carried out by 40 institutions involved in the CREATOUR project, located in the four NUTS II regions of Continental Portugal (Norte, Centro, Alentejo and Algarve).

The CREATOUR project "Creative Tourism Destination Development in Small Cities and Rural Areas" (https://creatour.pt/en/) was in process from November 2016 to June 2020. As a research-andapplication project, CREATOUR developed an integrated approach to creative tourism development in small cities and rural areas across Portugal. On the research side, the project aimed to examine and reflect on the creative tourism activities, including development dynamics and patterns, reception experiences, and community impacts, using methodologies and theoretical perspectives from the fields of tourism, cultural development, and local/regional development. On the practice side, it aimed to catalyse creative tourism offers in small cities and rural areas in Portugal, inform and learn from their development, and link them with each other through the development of a national network (Duxbury, 2020). The project was funded by FEDER through the Joint Activities Programme of COMPETE 2020 and the Regional Operational Programmes of Lisbon and Algarve and co-funded by the Portuguese Foundation for Science and Technology (FCT/MEC).

Taking a cultural development approach, CREATOUR fostered a diversity of "bottom-up" ideas and experimentation in which 40 pilot projects were independently designed, implemented, and managed, but coupled with knowledge-sharing and capacity-building through networking. The creative tourism activities developed ranged widely, including: craft workshops involving textile, pottery, ceramics, leather, metal, and wood; fine arts workshops such as painting, sculpture, drawing, and illustration; photography, video, and digital arts workshops; performing arts workshops and community-engaged, participatory artistic residencies; storytelling sessions and workshops; gastronomy-focused workshops in which visitors learn food-related cultures of a place as well as culinary techniques to take home; imaginative "Walks \& Visits" involving creation activities; ancestral traditions workshops and active participation activities; and activities related to raw materials production and work cycles for making, for example, salt, linen, wool, clay, marble, wicker, and so forth.

This paper aims to characterize the profile of the tourists who participated in these activities and their motivations, attending to the following three questions: Who are the participants in creative tourism activities? What are the main motivations to attend a creative tourism activity? Can motivation be used to segment creative tourism participants (i.e., are creative tourists motivation-driven)?

For the analysis of the data, descriptive and multivariate statistics have been developed through the program Statistical Package for the Social Sciences (S.P.S.S. version 22.0).

This paper is organized as follows. After the Introduction, section 2 presents a literature review of creative tourism and the creative tourist. The research methods are presented in section 3 . The results and discussion are presented in section 4. Finally, in section 5 the conclusions and some policy and managerial implications are presented.

\section{From cultural tourism to creative tourism and defining creative tourists}

\subsection{Characteristics of creative tourism and of creative tourists}

The development of creative tourism phenomena is linked to recent developments in cultural tourism. Cultural tourism corresponds to the tourism in which cultural attractions are the main reason to visit or stay in a certain destination (Csapó, 2012; Mousavi, Doratli, Mousavi, \& Moradiahari, 2016; Richards \& Wilson, 2006; Williams, 2010) and that offers the visitor an opportunity to understand and appreciate the culture and essence of a place (Kajzar, 2013, 2014; Richards, 2014b).

Creative tourism emerged in response to a market that has specific needs. Although it is the central theme of a growing number of investigations, the concept of creative tourism still remains quite vague in the scientific environment (Richards, 2011, 2014b; Tan et al., 2013; Hung, Lee, \& Huang, 2016; Smith, 2016; Creative Tourism Network, 2018; Remoaldo et al., 2019; Remoaldo, Matos, Gôja, Alves, \& Duxbury, 2020; Duxbury \& Richards, 2019a). Many definitions of creative tourism are linked to cultural tourism, and is generally understood as a form of cultural tourism that allows for a more authentic approach between the tourist and residents (Briggs, 2005; Gordin \& Matetskaya, 2012; Jelinčić \& Žuvela, 2012; King, 2009; Ohridska-Olson \& Ivanov, 2010; Richards, 2010b; Richards, 2014a; Richards \& Raymond, 2000; Virginija, 2016). Creative tourism is oriented to immaterial resources such as learning, developing experiences and traditions (Ribeiro et al., 
2020). This tourist is someone who wants to not only see the region but to experience it (Virginija, 2016). In this sense, creative tourism is a participatory form of cultural tourism more appropriate to contemporary social and economic structures. This type of tourism makes use of the intangible resources of the destination (e.g., lifestyles, narratives, creativity, media) and enables the tourist to participate actively in leisure, cultural and artistic activities that reflect the characteristics of the destination visited. It is a special form of tourism that creates the necessary conditions for travellers to exercise their and participate in creative workshops and activities (e.g., arts and heritage - Brouder, 2012; Rudan, 2012; Hung et al., 2016), which allows for a truer and more authentic experience in the destination.

This new demand for deep immersion in the experiences consumed reveals a new profile of tourist. Although there are attempts to characterize this new tourist (Carvalho, Ferreira, \& Figueira, 2011; Florida, 2002; Mota, Remoaldo, \& Ribeiro, 2012; Remoaldo \& Ribeiro, 2017; Remoaldo, Vareiro, \& Ribeiro, 2017; Richards, 2010a; Richards \& Wilson, 2007; Silberberg, 1995; Tan et al., 2014), no consensus has yet been found.

This new tourist wants a more authentic experience, immersed in the local cultural capital and close to the community (Guerreiro \& Marques, 2017; Remoaldo et al., 2020). This trend is a response to the saturation of mass cultural tourism (Richards, 2010a). In this sense, creative tourism develops the social and cultural capital of tourists, as they become co-authors of their tourism experience, contributing to authentic, immersive and exclusive experiences (Pine \& Gilmore, 1999; Richards, 2014b; Virginija, 2016).

\subsection{Characteristics of the participants in creative tourism activities}

The characteristics of the cultural tourist are very close to the ones of the traveller seeking creative experiences. Cultural tourists, for the most part, exhibit different expectations and motivations from those of the "modern" tourists (Smith, 2003). One of the characteristics that distinguishes cultural tourists from the people who engage in creative activities comes from the intensity of the motivations (which may be, to a greater or lesser extent) to live new experiences, as well as the degree of involvement and interaction that the tourist establishes with the local community (Smith, 2016). Creative tourists seek to enjoy participatory and authentic experiences and, mainly, generate their own experiences (Prahalad \& Ramaswamy, 2004), exercising co-creation (Binkhorst, 2007; Puczkó, 2013). Throughout the twentieth century, the attitude of tourists has undergone several changes and, on the whole, tourists have become more demanding. They have begun to look for experiences during their holidays as a way to develop their skills and take an active part in the culture of a place (Richards, 2010b).

This search for learning is not an absolutely new and intrinsic feature of the creative tourist. Completely to the contrary, this characteristic has been gaining expressiveness over the last two decades and is a central element of the experiences in creative tourism (Anderson, 2009; Peters, Frehse, \& Buhalis, 2009; Raymond, 2007; Tan et al., 2013).

These tourists wish to contact and learn more about specific aspects of the culture of a particular community through active participation with the local community and the development of their creative skills in workshops and other activities (Cortada, 2006; Raymond, 2003; Richards, 2003; Richards \& Raymond, 2000; Richards \& Wilson, 2007).

This kind of tourist assumes the role of co-creator, co-producer and consumer of the experiences and skills of the promoters of experiences (e.g., trainers, local community), that is, the tourist is involved in the local culture through making artefacts or products in the destination (e.g., handicrafts, gastronomy, art) (Anderson, 2009; Binkhorst, 2007; Maisel, 2009; Peters et al., 2009; Prentice \& Andersen, 2007; Ray \& Anderson, 2000; Raymond, 2007; Richards \& Wilson, 2006; Tan et al., 2013). In addition, the participant in creative tourism activities wants higher levels of social, emotional and educational interaction with the community and to feel like part of the destination (Binkhorst \& Den Dekker, 2009; Richards, 2014b; Smith, 2016; Stolarick, Denstedt, Donald, \& Spencer, 2010).

Investigations previously carried out on the profile of the creative tourist reveal that the existing segments are different and show that the creative tourist covers a wide range of travellers. What we do know is that the creative tourist tends to appreciate authenticity and cultivates the desire to get to know the local culture in a more "alternative" way that is closer to the local community.

Despite these attempts, the definition of the creative tourist is still very generalist and imprecise, many studies that claim to be about the creative tourist do not actually correspond to that segment of tourism, and further research about the creative tourist is still needed (Duxbury \& Richards, 2019b). In the next section, some international case studies are reviewed that present more detailed information on the profile of the creative tourist.

\subsection{Some case studies to define the profile of creative tourism seekers}

Creative tourism seekers tend to belong to the creative class (Florida, 2002), that is, a cosmopolitan class from the middle and upper layers of society which shares higher levels of education. Internationally, a few research surveys present the characteristics and behaviour of these contemporary tourists (see Table 1), but the body of research is still very limited and needs further theoretical development.

Table 1

International studies about creative tourist's profile

\begin{tabular}{|c|c|c|c|}
\hline Year & Author & Country & Creative tourist profile \\
\hline 2003 & Raymond (2003) & New Zealand & $\begin{array}{l}\text { Three groups: baby-boomer and retired, tourists under } 30 \text { (e.g., students and backpackers visiting New Zealand) and New } \\
\text { Zealanders of all ages. }\end{array}$ \\
\hline 2010 & Campbell (2010) & UK & $\begin{array}{l}\text { Predominantly female, } 45 \text { or more years of age. The other large group was made up of younger women aged between } 22 \\
\text { and } 30 \text { years of age with busy full-time jobs and no children. }\end{array}$ \\
\hline 2014 & Tan et al. (2014) & Taiwan & $\begin{array}{l}\text { Five distinct groups of creative tourists were identified: novelty-seekers, knowledge and skills learners, those who are } \\
\text { aware of their travel partners' growth, those who are aware of green issues, and the relax and leisure type. }\end{array}$ \\
\hline 2014 & $\begin{array}{l}\text { Chang, Backman, and Huang } \\
\text { (2014) }\end{array}$ & Taiwan & The largest number of tourists was between 31 and 40 years of age. Males comprised $40.8 \%$ and females made up $59.2 \%$. \\
\hline 2015 & Blapp & Indonesia & $\begin{array}{l}\text { Most tourists find it memorable to attend a cooking class, ride cows, take part in the daily lives of the population of Bali } \\
\text { and visit a rice plantation. }\end{array}$ \\
\hline 2016 & Ali, Ryu, and Hussain (2016) & Malaysia & $\begin{array}{l}\text { Most tourists were between } 31 \text { and } 40 \text { years of age ( } 60 \%) \text {. Males comprised } 46 \% \text { and females } 54 \% \text {. Most of the tourists } \\
\text { were Malaysian ( } 72 \%) \text { and } 28 \% \text { foreigners. The survey was conducted with guests of } 6 \text { selected resort hotels in Malaysian } \\
\text { states of Terengganu and Kedah. Creative activities: cooking classes, handicraft classes, storytelling sessions of local tales } \\
\text { and 'batik painting'. }\end{array}$ \\
\hline 2019 & $\begin{array}{l}\text { Huang, Chang, and Backman } \\
\text { (2019) }\end{array}$ & Taiwan & $\begin{array}{l}\text { By age, the largest number of tourists was between } 31 \text { and } 40 \text { years of age. Males comprised } 40.8 \% \text { and females made up } \\
59.2 \% \text {. The survey was carried out in three popular creative tourism attractions in Taiwan. Creative activities: pottery, } \\
\text { handicrafts and arts making. }\end{array}$ \\
\hline
\end{tabular}

Source: Authors' elaboration. 
In the early 2000s, Raymond (2003), based on a case study in New Zealand (Table 1), presented a proposal to segment and profile creative tourism seekers based on general demographic profiles, proposing three groups: baby-boomers and retired, tourists under 30 (e.g., students and backpackers) and New Zealanders who are interested in learning more about different aspects of the culture of their country.

In 2009, a survey of participants from two creative tourism pilot events in the UK concluded that the participants were predominantly female, aged 45 or more years of age. The other large group was made up of younger women aged between 22 and 30 with busy full-time jobs and no children (Campbell, 2010).

In 2014, Tan et al. identified five distinct groups of creative tourists in Taiwan - novelty-seekers, knowledge and skills learners, those who are aware of their travel partners' growth, those who are aware of green issues, and the relax and leisure type - by analysing 46 Q-statements about creativity and creative experiences.

In 2015 in Bali, Indonesia, another attempt to establish the profile of the creative tourist in creative tourism experiences of rural communities was presented by Blapp (2015). In total, 15 tourists' groups were interviewed based on an opportunistic sampling strategy. The interviews were limited to Western tourists given the scope of the research to focus on creative tourism geared toward the Western market (Blapp, 2015).

In 2016, Ali et al. examined the effect of creative tourists' experiences on their memories, satisfaction and behavioural intentions. A total of 296 surveys were conducted with guests at six selected resort hotels in Malaysian states of Terengganu and Kedah who participated in creative activities, cooking classes, handicraft classes, storytelling sessions of local tales and 'batik painting'. The largest number of tourists was aged between 31 and 40 years (60\%). Females were predominant (54\%), with three-quarters of them being Malaysian (72\%) and around one-quarter being foreigners (28\%).

In 2019, Huang et al. conducted an empirical study in three popular creative tourism attractions in Taiwan: Meinong, Singang and Yingge. The following creative activities were developed: pottery, handicrafts and arts making. The majority of the 395 tourists surveyed was aged between 31 and 40 years and females were also predominant (59.2\%).

In Portugal, a study on the influence of the creative industries on tourism in the city of Porto (City Break predominant tourism segment) presented the tourist profile in this city. In the sample collected of 385 tourists, males were predominant and their motivations were broader than participating only in creative activities. The tourists were from Spain, aged between 19 and 25 years, single, with a high academic degree (bachelors or masters) and with high annual income $(€ 15,000-€ 22,499)$ (Barbosa, 2014). Concerning their motivations, for $65 \%$ of the respondents the main reason for their trip to Porto was a vacation, $18 \%$ visited the city to visit friends or relatives and $5 \%$ visited to attend cultural events or attractions. Regarding attending cultural or creative activities, $47 \%$ of respondents in this research responded positively (e.g., participating in Serralves em Festa, NOS Primavera Sound, São João, Queima das Fitas, AXA Street Art, Verão na Casa da Música) while $53 \%$ did not attend any cultural or creative activity (Barbosa, 2014).

Another study developed by Melo, Correia, Cardoso, and Marques (2019) analysed the perspectives of visitors and suppliers concerning the experiences of creative tourism in Guimarães, Portugal (a UNESCO World Heritage destination) and identified that the majority of the respondents had not heard about creative tourism before $(82 \%$ in total; $n=115$ ). The authors reported that $50.7 \%$ were male and between 38 and 49 years old, and highlighted that $80 \%$ of the tourists come from the following countries: $35.7 \%$ from Brazil, $18.8 \%$ from Spain and $12.5 \%$ from France. Most respondents had higher education degrees and an income higher than 501 euros/month.

Although these Portuguese studies are not precisely about the profile of the creative tourist, they are important contributions to the study of the profile and motivations of visitors and help us to understand the visitors' profile for Portuguese destinations.

As we have previously noted, unravelling the profile and motivations of the creative tourist is not an easy task. The case studies reviewed showed that research on the traits of those engaged in creative tourism profile is still a little explored path. One of the possible explanations for this omission is the complexity of creative tourism as a wide variety of activities can be consumed within the creative tourism label. One can ask the following questions: Do the characteristics of this profile depend on the type of activity consumed? For example, does the tourist who participates in the Estival Festival (held in the Centro Region of Continental Portugal) have the same characteristics (or similar characteristics) and motivations of a tourist who participates in a pottery workshop (held in the Alentejo Region of Continental Portugal)?

\section{Methods}

Our research was carried out in 2017 and 2018 with the participation of four research groups located in four regions of Continental Portugal: Norte, Centro, Alentejo, and Algarve. Overall, 814 questionnaires were completed by participants in the creative tourism activities implemented by the 40 pilot institutions that were selected to join the CREATOUR project (Fig. 1). A wide array of organizations located in small and medium-sized cities and rural territories had submitted project proposals to develop creative tourism offers, and the 40 organizations selected to be co-researchers in CREATOUR were monitored within the project until the end of 2019.

The research presented here segmented the tourists based on their motivation to participate in creative tourism activities and analysed the resulting profiles. The questionnaire was designed based on a literature review of creative tourism, tourist motivations and cultural tourist profiles. A total of 10 motivation items were considered in this study (Table 2). The questionnaire consisted of 31 closed questions oriented to the participant's profile, motivations, perceptions and evaluation of activities, as well as the impacts on the local economy (e.g., accommodation, meals and local commerce).

In order to analyse this data, Multivariate Statistics was used to simplify the data, describing the information through a small number of dimensions of analysis (Reis, 2001). Hair, Anderson, and Tatham (1998) state that there are traditionally three types of segmentation techniques, being mostly of an exploratory nature. Some of these techniques are in a general area of multivariate data analysis traditionally known as data reduction or reduction of dimensionality. Using SPSS Statistics 22.0, the first procedure (the exploratory factor analysis) started with motivation variables (Table 2). After this procedure, a hierarchical cluster analysis, based on the tourists' motivation using Ward's method and the Squared Euclidean distance, was carried out to identify homogenous groups of respondents. A three-cluster solution was identified based on the dendogram and the agglomeration schedule. From the analysis of the output, chi-square tests (for qualitative variables) and $t$-test (quantitative variables) were carried out to characterize the clusters and to identify statistically significant differences concerning the following topics: reasons to select the creative experience; socio-professional situation; marital situation; net monthly income of the household; educational qualification; age; local shop behaviour and general evaluation of the experience. A cross-tabulation analysis was also carried out to test the association between sociodemographic and travel behaviour dimensions (i.e., first time at destination, information source and travel companions) with the cluster membership of respondents (Tables 5 and 6). These analyses are presented in the next section. 


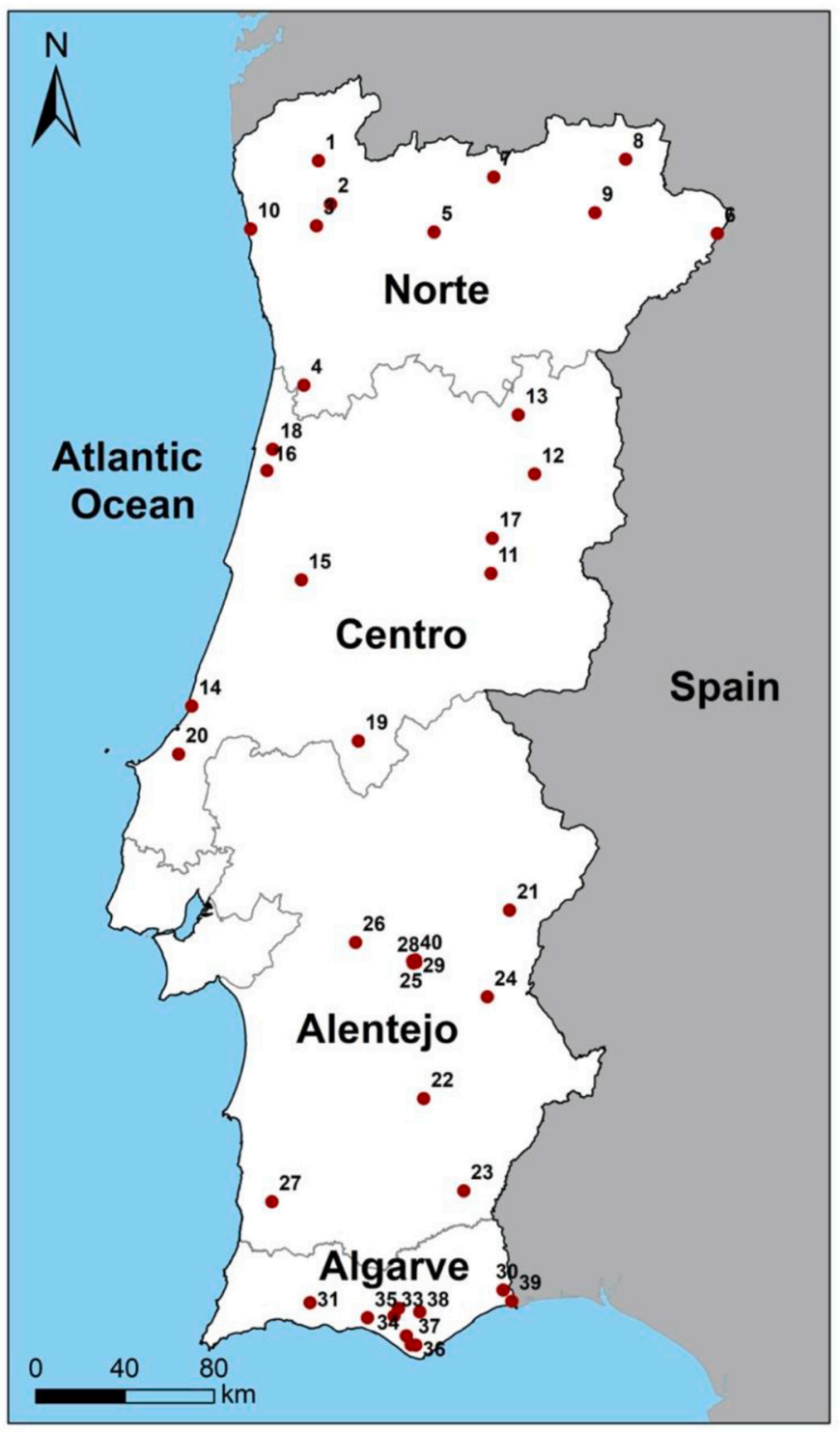

\section{- Pilot institution}

Pilot institution name

1-ADERE-PG

2- CM Amares

3- LRB - Investments and Consulting

4- CM S. João da Madeira

5- VERde NOVO

6- Galandum Galundaina

7-ADRAT

8- CM Bragança

9- Desteque

10- CM Esposende

11- ADXTUR

12- Domínio Vale do Mondego

13- Luzlinar

14- Quico Turismo

15- MosaicoLab

16- Ruralidades e Memórias

17- Tecitex+Wool Museum UBI

18- VIC // Aveiro Arts House

19- CM Abrantes

20-Destino Caldas

21- CECHAP

22- CM Beja

23- CM Mértola

24- CM Reguengos de Monsaraz

25- New Tradition

26- MARCA ADL

27- CACO

28- João Cutileiro Atelier

29- VAGAR Walking Tours

30- Odiana

31- Barroca

32- Proactivetur

33- CM Loulé

34- Tertúlia Algarvia

35- Espírito da Terra \& Co.

36- CCVAlg+Núcleo Algarve APM

37- Eating Algarve Food Tours

38- In Loco

39- Backup

40- Genuine Alentejo

$\frown$ Limit of continental Portugal

$\frown$ Limit of NUTS ॥

Fig. 1. Map of locations of the CREATOUR pilots. Source: Authors' elaboration.

\section{Results}

\subsection{Factor analysis results}

As a first stage of data analysis, an exploratory factor analysis was conducted to identify the dimensions of participants' motivation at creative tourism activities. Both the Kaiser-Meyer-Olkin (KMO) measure of sample adequacy (.801) and Bartlett's test of sphericity (1202.103) results revealed that the data was properly fitted for principal component analysis and responses were factor analysed with varimax rotation. For factor extraction, the criteria of Eigenvalues equal or above 1.0 was adopted, and factor loadings of at least .50 were accepted for item inclusion (Hair, Black, Babin, Anderson, \& Tatham, 2010 ). None of the items presented low factor loadings $(<.50)$, however "It is culturally motivating", "Because of the location" and "I Know the promoter of the activity" presented $.536, .589$ and .522 , respectively evidencing a value only slightly higher than .50 . Results obtained a three-factor solution that accounted for $55.5 \%$ of the total variance (Table 2). The following names were attributed to the items attributed to each factor: Creative; Partners and family togetherness; and Local community interaction. All factors had a sufficient reliability relying on Cronbach's Alpha coefficients ranging from .705 and .585. Although two of the factors present a .60 value, according to Hair et al. (2010, p. 124 ) the generally agreed upon lower limit for Cronbach's alpha is .70, although it may decrease to .60 in exploratory research.

\subsection{Cluster analysis results}

A cluster analysis was applied to identify a collection of individuals, based on the detailed information obtained, in relatively homogeneous groups. Finally, application of hierarchical clusters allowed patterns to be detected in individuals through categorical and continuous variables. In particular, the hierarchical clustering technique is a process that allows for the organization of data into nested groups (Dash, Liu, Scheuermann, \& Tan, 2003). In this way, categorical variables were added (reasons to select a creative tourism activity; socio-professional situation; marital status; educational qualifications; shop behaviour at local shops; general evaluation of the experience) as well as quantitative variables (counts) organized by groups (age and net monthly income of the household) in order to ascertain how many natural groups could be observed. A total of three groups were identified, with a total of 221 (33.6\%), 211 (32.1\%) and 225 (34.2\%) obtained for Groups 1, 2 and 3 respectively (Table 3 ). To identify statistically significant differences between the three-cluster solution, a Kruskal-Walis test was 
Table 2

Dimensions of creative tourists' motivations

\begin{tabular}{|c|c|c|c|c|}
\hline \multirow{2}{*}{$\begin{array}{l}\text { Motivation to select a tourism } \\
\text { creative experience }\end{array}$} & \multicolumn{3}{|c|}{ Components } & \multirow[t]{2}{*}{ Factors } \\
\hline & 1 & 2 & 3 & \\
\hline It is original & 0.772 & & & Creative \\
\hline For being fun & 0.761 & & & \\
\hline To stimulate my creativity & 0.712 & & & \\
\hline $\begin{array}{l}\text { It is suitable for the whole } \\
\text { family }\end{array}$ & & 0.681 & & $\begin{array}{l}\text { Partners and family } \\
\text { togetherness }\end{array}$ \\
\hline Because of its location & & 0.589 & & \\
\hline To accompany someone & & 0.831 & & \\
\hline It is culturally motivating & & & 0.536 & Local community \\
\hline $\begin{array}{l}\text { It permitted interaction with } \\
\text { other participants }\end{array}$ & & & 0.698 & interaction \\
\hline $\begin{array}{l}\text { It enables me to meet and } \\
\text { interact with the local } \\
\text { community }\end{array}$ & & & 0.736 & \\
\hline $\begin{array}{l}\text { I know the promoter of the } \\
\text { activity }\end{array}$ & & & 0.522 & \\
\hline Cronbach's Alpha & 0.705 & 0.591 & 0.585 & \\
\hline Eigenvalues & 3.187 & 1.280 & 1.079 & \\
\hline$\%$ variance explained & 31.874 & 12.803 & 10.790 & \\
\hline$\%$ variance cumulative & 31.874 & 44.677 & 55.466 & \\
\hline KMO (Kaiser-Meyer-Olkin) & 0.801 & & & \\
\hline
\end{tabular}

Bartlett's test of sphericity: Chi-squared $=1.202 .103 \mathrm{sig}$. (.000).

Extraction Method: Principal Component Analysis; Rotation Method: Varimax with Kaiser Normalization.

Cronbach's Alpha-Internal consistency.

Source: Authors' elaboration.

Table 3

Cluster distribution-Hierarchical cluster

\begin{tabular}{lllll}
\hline Ward method & & $\mathrm{N}$ & \% Valid & Kruskal-Wallis ( $\alpha)$ \\
\hline \multirow{2}{*}{ Cluster } & 1 & 221 & $33.6 \%$ & \multirow{2}{*}{$189.294(0.000)$} \\
& 2 & 211 & $32.1 \%$ & \\
\multirow{2}{*}{ Total } & 3 & 225 & $34.2 \%$ & \\
& & 657 & $100 \%$ & \\
\hline
\end{tabular}

Source: Authors' elaboration.

applied and it shows that each group was different from each other.

Considering results from a one-sample $t$-test with a test value of 4 (Table 4), respondents evidenced a positive motivation towards creative tourism activities, except "to accompany someone" with a mean score of 3.19 ( $t$-value $=-13.589, p$-value $<0.000)$ and "I know the promoter of the activity" with a mean score of 2.63 ( $t$ value $=-20.156, p$-value $<0.000$ ).

Table 4 compares the motivations of each cluster and Tables 5 and 6 show the profile of each group with respect to select demographic and travel behaviour characteristics. The clusters are described below according to their main characteristics.

Cluster 1 (Novelty-Seekers): This cluster includes $33.6 \%$ of the participants, with high motivations in the factor dimensions of Creative (higher mean score-"It is original") and Local community seekers (higher mean score - "It is culturally motivating"). In terms of sociodemographic characteristics, most are from the 18-35 years old group (37.4\%) and the 36-53 years old group (34.2\%) and, in terms of marital status, $61.8 \%$ are single and $29.7 \%$ are married, which means that they are mostly young individuals and middle-aged couples. They are well qualified, with bachelor degrees (39.5\%) and postgraduate degrees (26.1\%). Considering the travel behaviour dimension, results reveal that individuals travelled with someone $(73.2 \%)$ : travelling with their child $(27.6 \%)$, with an organized group $(35.2 \%)$ or with friends (34.3\%). Within this cluster, $79.0 \%$ of the participants stated that the creative tourism activity was the primary reason for their visit. This group was named Novelty-Seekers because they tend to highly score on motivations which can be relevant to their engagement in actions of originality, fun and that stimulate creativity while, at the same time, they seek contact with other participants and with the local community.

Cluster 2 (Knowledge and Skills Learners): This cluster includes $32.1 \%$ of the participants and it scored between the other two groups except in "To stimulate my creativity"; "It permitted interaction with other participants" and "I Know the promoter of the activity". However, it is evident that with a higher score within the Local community seekers factor (higher mean score - "It is culturally motivating") and in the Creative factor (higher mean score - "It is original"), additionally and comparing with the group 1 , this cluster presents a higher mean score within the Socializers factor ("To accompany someone"). In terms of sociodemographic characteristics, most are aged between 18-35 years old $(28.3 \%)$ and $36-53$ years old $(37.6 \%)$ and, in terms of marital status, $53.1 \%$ are single and $39.3 \%$ are married. They are well qualified, with bachelor degree (28.3\%) and postgraduate degree (34.6\%). Considering the travel behaviour dimension, results reveal that individuals predominantly travelled with someone (90\%): travelling with their spouse/partner (40.1\%), with their children (40.0\%) and with their family (42.6). Within this cluster, $67.8 \%$ of participants indicated that this creative tourism activity was the primary reason of their visit to the locale. This group was named Knowledge and Skills Learners because they tend to highly score motivations that imply their engagement in

Table 4

Comparison of cluster's motivation

\begin{tabular}{|c|c|c|c|c|c|c|c|c|c|c|}
\hline \multirow{2}{*}{$\begin{array}{l}\text { Motivation to select a tourism creative } \\
\text { experience }\end{array}$} & \multirow[t]{2}{*}{ Factor dimensions } & \multicolumn{4}{|l|}{ Total } & \multicolumn{3}{|l|}{ Clusters } & \multicolumn{2}{|c|}{ Kruskal Wallis Test } \\
\hline & & Mean & S.D. & $t$-value & $p$-value & $\begin{array}{l}\text { Novelty- } \\
\text { seekers }\end{array}$ & $\begin{array}{l}\text { Knowledge and skills } \\
\text { learners }\end{array}$ & $\begin{array}{l}\text { Leisure creative- } \\
\text { seekers }\end{array}$ & $\chi^{2}$ & Sig. \\
\hline It is original & Creative & 4.46 & 0.74 & 17.373 & 0.000 & 4.40 & 4.41 & 4.59 & 8.99 & 0.011 \\
\hline For being fun & & 4.28 & 0.86 & 9.036 & 0.000 & 4.12 & 4.29 & 4.45 & 11.947 & 0.003 \\
\hline To stimulate my creativity & & 4.23 & 0.91 & 6.938 & 0.000 & 4.22 & 4.10 & 4.40 & 12.652 & 0.002 \\
\hline It is suitable for the whole family & $\begin{array}{l}\text { Partners and family } \\
\text { togetherness }\end{array}$ & 4.00 & 1.18 & 0.186 & 0.852 & 3.36 & 4.18 & 4.50 & 89.297 & 0.000 \\
\hline Because of its location & & 3.88 & 0.99 & -3.303 & 0.001 & 3.43 & 3.79 & 4.60 & 86.231 & 0.000 \\
\hline To accompany someone & & 3.20 & 1.61 & -13.589 & 0.000 & 1.02 & 4.22 & 4.70 & 12.652 & 0.002 \\
\hline It is culturally motivating & $\begin{array}{l}\text { Local community } \\
\text { interaction }\end{array}$ & 4.73 & 0.79 & 25.783 & 0.000 & 4.63 & 4.65 & 4.80 & 9.702 & 0.008 \\
\hline $\begin{array}{l}\text { It permitted interaction with other } \\
\text { participants }\end{array}$ & & 4.13 & 0.91 & 4.047 & 0.000 & 4.01 & 3.98 & 4.90 & 24.092 & 0.000 \\
\hline $\begin{array}{l}\text { It enabled me to meet and interact } \\
\text { with the local community }\end{array}$ & & 4.28 & 0.80 & 9.615 & 0.000 & 4.11 & 4.27 & 4.10 & 11.968 & 0.003 \\
\hline I know the promoter of the activity & & 2.63 & 1.81 & -20.156 & 0.000 & 2.21 & 1.00 & 4.11 & 420.879 & 0.000 \\
\hline
\end{tabular}

$t$-Test (value $=4 \mid$ significant at 0.01 level).

Source: Authors' elaboration. 
Table 5

Clusters profile by sociodemographic characteristics

\begin{tabular}{|c|c|c|c|c|c|c|c|}
\hline \multirow{2}{*}{$\begin{array}{l}\text { Variables/Categories } \\
\text { Sociodemographic }\end{array}$} & \multicolumn{2}{|l|}{ Total } & \multicolumn{3}{|l|}{ Clusters (\%) } & \multicolumn{2}{|c|}{ Chi-Square } \\
\hline & $\mathrm{N}$ & $\%$ & Novelty-seekers & Knowledge and skills learners & Leisure creative-seekers & $\chi^{2}$ & Sig. \\
\hline Gender & 798 & & & & & & \\
\hline Female & & 63.8 & 67.0 & 59.6 & 59.8 & n.s. & n.s. \\
\hline Male & & 36.2 & 33.0 & 40.4 & 40.2 & & \\
\hline Nationalities & 796 & & & & & & \\
\hline Portugal & & 75.4 & 71.9 & 73.5 & 74.7 & n.s. & n.s. \\
\hline Spain & & 6.3 & 7.7 & 3.8 & 6.7 & & \\
\hline The Netherlands & & 6.0 & 6.3 & 8.5 & 4.4 & & \\
\hline Brazil & & 2.3 & 3.6 & 1.4 & 2.2 & & \\
\hline Others & & 10.1 & 10.5 & 12.8 & 12.0 & & \\
\hline Age & 796 & & & & & & \\
\hline$<17$ & & 12.6 & 10.5 & 18.5 & 9.0 & 15,307 & 0.053 \\
\hline $18-35$ & & 28.5 & 37.4 & 28.3 & 30.5 & & \\
\hline $36-53$ & & 35.6 & 34.2 & 37.6 & 39.5 & & \\
\hline $54-64$ & & 14.8 & 11.0 & 11.2 & 13.9 & & \\
\hline$=>65$ & & 8.5 & 6.8 & 4.4 & 7.2 & & \\
\hline Education & 779 & & & & & & \\
\hline Elementary degree & & 9.5 & 11.2 & 11.7 & 5.0 & 32.003 & 0.004 \\
\hline Secondary degree & & 27.6 & 23.2 & 24.5 & 33.5 & & \\
\hline University degree & & 34.7 & 39.5 & 28.3 & 38.1 & & \\
\hline Post/graduate degree & & 27.9 & 26.1 & 34.6 & 23.4 & & \\
\hline Other & & 0.4 & 0.0 & 1.0 & 0.0 & & \\
\hline Marital Status & 755 & & & & & & \\
\hline Single & & 53.6 & 61.8 & 53.1 & 54.9 & 13.669 & 0.034 \\
\hline Married & & 36.7 & 29.7 & 39.3 & 38.0 & & \\
\hline Divorced & & 7.9 & 5.7 & 7.1 & 7.1 & & \\
\hline Widow & & 1.7 & 2.8 & 0.5 & 0.0 & & \\
\hline Household's net monthly income & 595 & & & & & & \\
\hline up to $500 €$ & & 8.9 & 12.3 & 5.8 & 9.4 & n.s. & n.s. \\
\hline $501 €-1000 €$ & & 24.5 & 22.8 & 25.6 & 26.5 & & \\
\hline $1001 €-2500 €$ & & 43.0 & 43.9 & 38.5 & 43.5 & & \\
\hline $2501 €-4000 €$ & & 14.5 & 11.7 & 19.9 & 12.9 & & \\
\hline more than $4001 €$ & & 9.1 & 9.4 & 10.3 & 7.6 & & \\
\hline Socio-professional Situation & 756 & & & & & & \\
\hline Manager/professionals & & 9.4 & 6.2 & 11.1 & 10.4 & n.s. & n.s. \\
\hline Specialists in academic and intellectual activities & & 23.4 & 28.0 & 25.3 & 17.0 & & \\
\hline Technicians and associate professionals & & 13.8 & 13.7 & 14.6 & 16.0 & & \\
\hline Administrative workers & & 4.1 & 3.8 & 3.5 & 3.8 & & \\
\hline Service and sales workers & & 3.0 & 2.4 & 2.5 & 5.7 & & \\
\hline Skilled agricultural, forestry and fishery workers & & 0.7 & 0.0 & 0.5 & 0.9 & & \\
\hline Craft and related trades workers & & 0.8 & 0.9 & 0.5 & 0.9 & & \\
\hline Retired & & 9.1 & 10.0 & 4.0 & 7.50 & & \\
\hline Domestic & & 2.0 & 0.5 & 2.0 & 1.4 & & \\
\hline Student & & 21.3 & 23.2 & 25.8 & 19.3 & & \\
\hline Unemployed & & 5.4 & 7.1 & 4.0 & 6.1 & & \\
\hline Other & & 6.2 & 4.3 & 6.1 & 10.4 & & \\
\hline
\end{tabular}

Source: Authors' elaboration.

actions of originality, fun, and to participate in creativity-stimulating activities together with their travel companions, while at the same time they seem to seek contact with the local community.

Cluster 3 (Leisure Creative-Seekers): This cluster includes $34.2 \%$ of participants and scored high in every motivation, with the two higher mean scores in the local community seekers dimension ("It permitted interaction with other participants" and "It is culturally motivating"). Middle-aged participants prevail (39.5\%), but the young group of participants (18-35 years of age) also comprise an important percentage $(30.5 \%)$ and the majority of individuals are single $(54.9 \%)$. In terms of education, they are also qualified with a university degree (38.1\%), but a considerable part of this group has high school education (33.5\%). Considering their travel behaviour, $83.8 \%$ travel with someone, and among those who travel with companions, $33.9 \%$ travel with spouse/partner and $36.5 \%$ with their family. The majority of participants indicated that this creative tourism activity was the primary reason for their visit $(72.9 \%)$. This group was named Leisure Creative-Seekers because they tend to highly score all motivations that imply their engagement in creative tourism activities is based on a perception of it as an educational and creative experience that can positively affect their emotions and stimulate them to activate their creative dimension during their travel experience.

Cluster 1 (Novelty-Seekers) and Cluster 2 (Knowledge and Skills Learners) consider "culturally motivating" as the most important motivator to select a creative tourism activity, whereas Cluster 3 (Leisure Creative-Seekers) consider "interaction with other participants" as the most important motivation. It is important to underline that "to accompany someone" is the least important motivation for Cluster 1; however, this is one of the most important motivators for Cluster 3. In the same vein, "I know the promoter of the activity" is the most important motivator for Cluster 3, whereas for Clusters 1 and 2 it is the least important motivator. These points highlight the main differences between each cluster concerning their motivations to select creative tourism experiences.

Overall, the sample is constituted by a considerable number of females (63.8\%). In terms of marital status, $53.6 \%$ are single and $36.7 \%$ are married, and $63 \%$ are highly qualified with university degree (Table 5).

Within a professionally active age (78.9\% aged between 18-65 years old), $23.4 \%$ are "Specialists in intellectual and academic 
Table 6

Clusters profile by travel behaviour characteristics

\begin{tabular}{|c|c|c|c|c|c|c|c|}
\hline \multirow{2}{*}{$\begin{array}{l}\text { Variables/Categories } \\
\begin{array}{l}\text { Travel behaviour: first time at destination and activity; information; travel } \\
\text { companions }\end{array}\end{array}$} & \multicolumn{2}{|c|}{ Total } & \multicolumn{3}{|l|}{ Clusters (\%) } & \multicolumn{2}{|c|}{ Chi-Square } \\
\hline & $\mathrm{N}$ & $\%$ & Novelty-seekers & $\begin{array}{l}\text { Knowledge and skills } \\
\text { learners }\end{array}$ & $\begin{array}{l}\text { Leisure creative- } \\
\text { seekers }\end{array}$ & $X^{2}$ & Sig. \\
\hline Accompanied & 810 & & & & & & \\
\hline Yes & & 82.0 & 73.2 & 90.0 & 83.8 & 21.523 & 0.000 \\
\hline No & & 18.0 & 26.8 & 10.0 & 16.2 & & \\
\hline Travel Companion & 664 & & & & & & \\
\hline Spouse/partner & & 25.2 & 26.0 & 40.1 & 33.9 & 6.697 & 0.041 \\
\hline Child(ren) & & 15.4 & 27.6 & 40.0 & 32.4 & & \\
\hline Family & & 16.1 & 20.9 & 42.6 & 36.5 & & \\
\hline Friend(s) & & 24.3 & 34.3 & 33.1 & 32.6 & & \\
\hline Organized group & & 19.0 & 35.2 & 32.0 & 32.8 & & \\
\hline Was this the first time you have participated in a creative tourism experience? & 809 & & & & & & \\
\hline Yes & & 68.1 & 67.0 & 71.0 & 62.5 & n.s. & n.s. \\
\hline No & & 31.9 & 33.0 & 29.0 & 37.5 & & \\
\hline $\begin{array}{l}\text { Was this creative tourism activity the primary reason for your visit to this } \\
\text { locale? }\end{array}$ & 765 & & & & & & \\
\hline Yes & & 74.2 & 79.0 & 67.8 & 72.9 & 6.662 & 0.036 \\
\hline No & & 25.8 & 21.0 & 32.2 & 27.1 & & \\
\hline How did you LEARN about this experience? & 814 & & & & & & \\
\hline Tourism guide/brochure/pamphlet & & 5.2 & 38.7 & 29.0 & 32.3 & & \\
\hline At my accommodation & & 2.9 & 23.5 & 47.1 & 29.4 & & \\
\hline Travel and tourism operators/agencies & & .6 & 33.3 & 33.3 & 33.3 & & \\
\hline Media (TV, radio and press) & & 3.9 & 50.0 & 7.7 & 42.3 & n.s. & n.s. \\
\hline Tourist information office & & 1.4 & 0.0 & 30.0 & 70.0 & & \\
\hline Website of the CREATOUR Project & & 3.2 & 36.8 & 26.3 & 36.8 & & \\
\hline Website of the activity organizer & & 11.5 & 44.9 & 30.8 & 24.4 & & \\
\hline Through family and friends & & 33.2 & 27.5 & 33.0 & 39.4 & & \\
\hline Social networks & & 25.6 & 45.7 & 21.4 & 32.9 & & \\
\hline Passing by & & 8.2 & 16.1 & 50.0 & 33.9 & & \\
\hline Did you stay or will you stay overnight in the locale? & 791 & & & & & & \\
\hline Yes & & 40.4 & 47.0 & 43.8 & 39.7 & n.s. & n.s. \\
\hline No & & 58.6 & 53.0 & 56.3 & 60.3 & & \\
\hline If yes, where did you stay? & 322 & & & & & & \\
\hline Hotel or similar establishment & & 37.9 & 37.3 & 37.3 & 25.5 & & \\
\hline Apartment/house for rent & & 15.8 & 25.6 & 53.8 & 20.5 & & \\
\hline Room rented in private home & & 3.1 & 22.2 & 55.6 & 22.2 & n.s. & n.s. \\
\hline Second residence & & 5.9 & 21.4 & 28.6 & 50.0 & & \\
\hline Accommodation provided free by family/friends & & 18.9 & 36.4 & 18.2 & 45.5 & & \\
\hline Other private accommodation & & 18.3 & 40.7 & 24.1 & 35.2 & & \\
\hline
\end{tabular}

Source: Authors' elaboration.

activities", $13.8 \%$ are "Technicians and associate professionals" and 9.4\% are "Managers/Professionals". The household's net monthly income from employment is between $1001 €$ and $2500 €$ (43\%). In terms of nationalities, $75.4 \%$ are from Portugal and $24.6 \%$ are from foreign countries. In terms of travel companions, $25.2 \%$ travel with their partner, $24.3 \%$ travel with friends, $19.0 \%$ travel in an organized group, $16.1 \%$ travel as a family and $15.4 \%$ travel with their child(ren). For a considerable number of people this was the first time participating in a creative tourism experience $(68.1 \%)$ and the creative tourism activity was the primary reason for visiting the destination (74.2\%). The majority of participants learned about this experience through family and friends (33.2\%), social networks (25.6\%) and the website of the activity organizer (11.5\%) (see Table 6).

\section{Discussion and conclusions}

This article aimed to characterize the profile of creative tourists and their motivations in Portugal. The research sought to answer the following questions: Who are the participants in creative tourism activities? What are the main motivations to attend a creative tourism activity? Can motivation be used to segment creative tourism participants?

\subsection{Discussion}

The main focus of the study is to identify and articulate the profile of creative tourism participants based on their sociodemographic characteristics, travel behaviour and motivations. Since the present study has an exploratory nature, in order to characterize the profile of these tourists, different groups of participants in creative tourism experiences were identified. Although a few previous studies (in various countries) identified several features of creative tourists, none of them clearly identified groups of individuals based on sociodemographic characteristics, travel behaviour and motivations in a context of small and medium-sized cities and rural areas. Also, they used a much smaller sample size than the one used in the current study.

To validate the motivations-item scale and consequently to support the designation of the identified dimension factors and clusters, findings from a variety of studies were incorporated into the analysis, such as Ryan and Glendon (1998) about the application of the leisure motivation scale to tourism; Tan et al.'s (2014) taxonomy of creative tourists; and the work on profiling creative tourists conducted by Raymond (2003), among others.

The Creative dimension factor was identified primarily based on the stated motivations about originality, fun and stimulation of the participant's creativity. This dimension partially corroborates with the characteristics of this form of tourism described by Brouder (2012), Rudan (2012) and Hung et al. (2016). The Partners and family togetherness dimension emerged as the factor linking participation in creative tourism activities with the need to share it with several types of travel companions, such as one's family. This dimension is grounded on Ryan and Glendon's (1998) research concerning the importance of the 
item "Be with others" to clarify the holiday motivation scale. Furthermore, Tan et al.'s (2014) taxonomy of creative tourists exerts the importance of items about "family togetherness" or to "take the opportunity to participate in an activity to be together with my family or friends". The Local community interaction factor is the most relevant motivation that contains items similar to the studies by Tan et al. (2014), Raymond (2003) and Ryan and Glendon (1998). Motivation items such as Interaction with other participants; Culturally motivated; and Meet and interact with the local community are highly rated, corroborating these previous studies.

Following the identification of factor dimensions, a segmentation procedure was adopted based on sociodemographic, travel behaviour and motivation-based criteria. In the cluster analysis, a data-driven segmentation approach (Dolnicar \& Grün, 2008; Mazanec, 2000) was conducted that relied on analysing the data collected to determine market segment profiles. The results reveal that participants of creative tourism activities consist of three distinct clusters. A first cluster, called Novelty-Seekers, comprises a high involvement in creative motivation factors, such as looking for fun, originality and creativity, but also with an appreciative degree of socialization with other participants and with the local community in order to learn about its culture. This cluster meets a few of the characteristics of the typologies of Crompton (1979) in what concerns motives to travel (push factors), particularly in the dimension of travel as a facilitator of social interaction. Novelty-Seekers are also framed into Crompton (1979), mainly in the dimension of travel to find novelty: "Synonyms included curiosity, adventure, new and different. Novel meant new experience but it did not necessarily mean entirely new knowledge" (p. 419). This segment corroborates also with Tan et al.'s (2014) typology of the novelty-seekers perspective, mainly due to the attraction of new activities and searching for new "creative" activities. The second cluster, named Knowledge and Skills Learners, comprises a high mean value inside three factor dimensions/ items: originality and culturally motivating, to accompany someone, and to meet and interact with the local community. This group is also characterized as the most academically qualified and more likely to travel with their family. Previous studies about the profile of the creative tourist found evidence of these types of characteristics for tourists who stated they are motivated to participate in a creative tourism activity to gain knowledge (Tan et al., 2014). In the same vein, studies by Richards (2014a) and Smith (2016) also emphasized educational interaction with the community, similar to this Knowledge and Skills Learners segment of creative tourists. The third segment, Leisure Creative-Seekers, comprises participants who evidence a high mean value in all of the motivation items. However, if we consider the top three items, two of them are concentrated in Local Community Interactors (interaction with other participants and culturally motivating) and the third is found in Knowledge and Skills Learners (to accompany someone). It is also important to underline that this cluster classified all the motivation items highly ( 4 or above, in a 1 to 5 Likert scale), which means that this cluster meets certain characteristics of the relax and leisure type of creative tourists found in the study by Tan et al. (2014) but also follows McKercher, Ho, du Cros, and Chow's (2002) cultural tourist typology, namely, the type of purposeful cultural tourist. The results also demonstrated an upgrade in several characteristics concerning the type of cultural tourists articulated by McKercher et al. (2002). For instance, the Leisure Creative-Seekers cluster highly ranked interaction with other participants and is motivated to participate in creative tourism activities to accompany someone, because it is original, because they know the promoter of the activity, and because it is suitable for the whole family. Following from this, creative tourism participants considered to be Leisure Creative-Seekers demonstrate a need to socialize and share the co-creation process with others during their experience. These results align with the conclusions of several studies concerning the tourist's involvement in the local culture through their participation in activities related with artefacts or other local products (e.g., Anderson, 2009; Cabeça, Gonçalves, Marques, \&
Tavares, 2020; Raymond, 2007; Tan et al., 2013, among others). Creative tourism participants place great importance on co-creation in creative tourism activities, which involves processes involving tourists and residents as full participants and not passive subjects (Binkhorst, 2008). Experiencing and interacting are key, with co-creation perceived as "a prerequisite for the definition of what a creative experience means and what it presupposes" (Cabeça et al., 2020, p. 12).

Finally, a brief remark on the sociodemographic and travel behaviour characteristics of the three clusters. As presented in Tables 2 and 3 , only variables that present as statistically significant should be considered as features for each cluster. In all the clusters, the age dimension shows that more than $60 \%$ of creative tourism participants are between 18 and 53 years of age, a result that is concordant with results of studies conducted by Raymond (2003), Campbell (2010) and Chang et al. (2014). In the same vein, education and marital status generally show similar results in all clusters. For instance, a considerable part of the three segments of creative tourists in this study are single and well educated, similar to the results gathered by Tan et al. (2014). In terms of their travel behaviour, in all clusters the tourists indicated that their primary reason to travel to that location was to participate in the creative tourism experience and almost all travel was accompanied. Taking all this into account, creative tourism can be a strategic development priority for tourism and culture in Portugal, especially in small cities and rural areas, and can be part of a tourism innovation model focused on local resources. There is a growing demand for local tourism products with higher added value, and interaction between participants and local residents as well as co-creation processes are key when choosing a destination. Having these characteristics associated with it, creative tourism meets the diverse needs and motivations of contemporary travellers and can constitute a diverse offer, combining with various types of existing tourism (e.g., cultural tourism, nature tourism, gastronomic tourism). In order to improve the desired relations among the participants in creative experiences and with the local community, it is important to empower practitioners from the tourism and cultural/ creative sectors to collaborate as tourism experience providers as well as other community members who can act as local community facilitators.

Beyond the socio-demographic characteristics of these creative tourism participants, this study also analyzes motivational characteristics, finding them to be similar to those identified in other studies internationally. This study's results reinforce the importance of the interaction component, which is one of the main characteristics of creative tourism, that is, the socialization and interaction of the visitors with the local community and also among the participants themselves. Understanding creative tourists' motivations enables promoters to develop activities that are more attractive and appropriate to meet travellers' expectations, thus constituting a more sustainable offer. In addition, the study introduces a strong element of desire for involvement in activities with one's travelling companions, that is, the search for creative tourism activities that promote activities for a family and/or among friends.

The study results indicate a shift in creative tourism towards a more interactional dynamic in which the bonds between participants and cocreation processes are highly valued. Placing emphasis on the interactional dimensions of creative tourism can amplify its meaning and prompt further research attention to the ways in which it materializes.

\subsection{Theoretical and managerial implications}

This study aimed to better know the profile of the creative tourist because it has been widely recognized that there is no clear definition of the creative tourist at an international or national level (Duxbury \& Richards, 2019b). Indeed, this is the first major study at the national or international level to investigate and segment the creative tourism market for activities in small and medium-sized cities and rural areas.

Beyond the socio-demographic characteristics of these creative 
tourism participants, this study also analyzes their motivational characteristics, finding them to be similar to those identified in other international studies. This study's results reinforced the importance of the interaction component, which is one of the main characteristics of creative tourism, that is, the socialization and interaction of visitors with the local community and also among the creative tourism participants themselves. In addition, the study introduces a strong element of involvement in activities among travelling companions, that is, a search for creative tourism activities that promote activities for a family and/or among friends.

\subsection{Limitations and future research}

As with any other research, this study has some limitations that should be highlighted. A primary dimension of these limitations is related to the data and sample design. The sample has different weight sizes among the Portuguese regions, focusing on the selected rural areas and small and medium-sized towns that are home to the creative tourism initiatives that were the focus of this research. The questionnaires were applied locally by the participating pilot organizations and centrally analyzed by the research teams. Consequently, the adopted sample method was by convenience. A second dimension is concerned with the motivations listed in the questionnaire relating to the creative tourism activities. This research has an exploratory nature, and future studies should further explore and possibly identify other type of motivations based on qualitative research (such as adopting these items and other items tested in previous studies to conduct semistructured interviews with creative tourists) in order to test and validate a scale of creative tourism motivations.

Looking forward, future methodological research following from this study includes the need to validate a scale of motivations for participants in creative tourism activities. Within the CREATOUR project, it would be valuable to conduct further analysis of the creative tourism participant profiles and motivations data in relation to the different types of creative tourism activities in which the tourists were engaged. Further additional quantitative and qualitative research involving international travellers would extend this research and also help to inform practitioners on how they can best prepare for and attract tourists to creative tourism activities based in small cities and rural areas. As the current study represents a snapshot of an emerging array of creative tourism initiatives in small cities and rural areas throughout Continental Portugal, it would also be valuable to extend this research over time so that a longitudinal perspective can be obtained as the initiatives develop, mature and evolve. As well, the extension of this research in a comparative framework involving creative tourism initiatives in other countries would be important to develop a more comparable data framework internationally for creative tourism.

\subsection{Creative tourism in the context of COVID-19}

In the context of the COVID-19 pandemic, creative tourism is well positioned to significantly contribute to post-pandemic tourism. Creative tourism is, by nature, designed for small groups (e.g., families and social bubbles). It aligns well with the growing focus on domestic tourism and longer stays in one place - exploring one's city, region, or country with new perspectives on its diversities; pursuing personal interests and curiosities; and developing new skills. The nature of activities within creative tourism is diverse, and its transversality is also a key strength, complementing and extending the offers of other types of tourism (Gonçalves, Borges, Duxbury, Carvalho, \& Costa, 2020). In smaller and rural communities, creative tourism can assist in providing activities for people staying for longer periods, and can be interconnected with nature and outdoors and restorative activities.

The pandemic has also alerted us to the high degree of precariousness for workers in the tourism sector, the impacts of tourism on local communities and the importance of communities in the scope of tourism. Altogether, there is a need to rethink tourism's traditional models. Going forward, tourism-resident communities have to take a more active role in establishing tourism agendas and planning for their re-booted local development trajectories. This highlights another future research line - generative relations between tourism and local communities. From now on, it is clear that tourism will necessarily have to take the health and well-being of communities into account when determining tourism approaches and agendas, and to (re)consider how tourism brings benefits to communities. From this vantage point, creative tourism is also well positioned. As a widely applicable approach to place-sensitive tourism development (Bakas, Duxbury, Silva, \& Vinagre de Castro, 2020), creative tourism can encourage and enable the diversification and differentiation of tourism offers in smaller places.

\section{Author contributions}

The authors contributed equally to this work.

\section{Acknowledgements}

This research was conducted within the project CREATOUR, "Creative Tourism Destination Development in Small Cities and Rural Areas" (Project 16437), which is funded by the Portuguese Foundation for Science and Technology (FCT/MEC) through national funds and cofunded by FEDER through the Joint Activities Programme of COMPETE 2020 and the Regional Operational Programmes of Lisbon and Algarve.

\section{References}

Ali, F., Ryu, K., \& Hussain, K. (2016). Influence of experiences on memories satisfaction and behavioral intentions: A study of creative tourism. Journal of Travel \& Tourism Marketing, 33(1), 85-100. https://doi.org/10.1080/10548408.2015.1038418.

Anderson, B. (2009). Yester-Morrow: using a region's heritage and culture for its economic future. In R. Wurzburger, T. Aegeson, A. Pattakos, \& S. Pratt (Eds.). Creative tourism: A global conversation (pp. 197-204). Santa Fe: Sunstone Press.

Hair, J., Anderson, R., \& Tatham, R. (1998). Multivariate data analysis (5th ed.). London: Prentice Hall.

Argent, N., Tonts, M., Jones, R., \& Holmes, J. (2013). A creativity-led rural renaissance? Amenity-led migration, the creative turn and the uneven development of rural Australia. Applied Geography, 44, 88-98. https://doi.org/10.1016/j.apgeog.2013.07. 018.

Bakas, F. E., Duxbury, N., Silva, S., \& Vinagre de Castro, T. (2020). Connecting to place through creative tourism. In S. M. Cabeç, A. R. Gonçalves, J. F. Marques, \& M. Tavares (Eds.). Creative tourism dynamics: Connecting travellers, communities, cultures, and places (pp. 119-139). Coimbra: Editora Grácio.

Barbosa, R. J. S. (2014). A influência das indústrias criativas sobre o turismo na cidade do Porto. Portugal: Escola Superior do Porto, IPAM The Marketing School Master's thesis.

Binkhorst, E. (2007). Creativity in tourism experiences: The case of Sitges. In G. Richards, \& J. Wilson (Eds.). Tourism, creativity and development (pp. 125-144). London: Routledge.

Binkhorst, E. (2008). Turismo de cocreación: valor añadido en escenarios turísticos. Journal of Tourism Research, 1(1), 40-51.

Binkhorst, E., \& Den Dekker, T. (2009). Agenda for co-creation tourism experience research. Journal of Hospitality Marketing \& Management, 18(2-3), 311-327 https://doi. org/10.1080/19368620802594193.

Blapp, M. (2015). Creative tourism in Bali's rural communities-Examination of the current offer and advice on future product development. Breda University of Applied Sciences, Netherlands: Unpublished doctoral thesis.

Boes, K., Buhalis, D., \& Inversini, A. (2015). Conceptualising smart tourism destination dimensions. In I. Tussyadiah, \& A. Inversini (Eds.). Information and communication technologies in tourism (pp. 391-403). Springer International Publishing.

Briggs, S. (2005). Cultural tourism. How you can benefit. VisitBritain advisory guide. VisitBritain: London.

Brouder, P. (2012). Creative outposts: Tourism's place in rural innovation. Tourism Planning \& Development, 9(4), 383-396. https://doi.org/10.1080/21568316.2012. 726254.

Cabeça, S. M., Gonçalves, A. R., Marques, J. F., \& Tavares, M. (2020). Creative tourism as an inductor of co-creation experiences: The CREATOUR project in the Algarve. In P. Pinto, \& M. Guerreiro (Eds.). Handbook of research on resident and tourist perspectives on travel destinationsPennsylvania: IGI Global [accepted].

Campbell, C. (2010). Creative tourism providing a competitive edge. Tourism Insights, 3(2), 55-68.

Carvalho, R., Ferreira, A. M., \& Figueira, L. M. (2011). O contributo dos eventos culturais e criativos para a criação de uma imagem diferenciadora do destino turístico maduro. 
O caso do festival MED de Loulé, Algarve. First international conference on tourism and management studies, 26-29 October 2011 (pp. 457-466). Faro: University of the Algarve.

Carvalho, R., Ferreira, A. M., \& Figueira, L. M. (2016). Cultural and creative tourism in Portugal. PASOS. Revista de Turismo y Patrimonio Cultural, 14(5), 1075-1082. https:// doi.org/10.25145/j.pasos.2016.14.071.

Chang, L. L., Backman, K. F., \& Huang, Y. C. (2014). Creative tourism: A preliminary examination of creative tourists' motivation, experience, perceived value and revisit intention. International Journal of Culture, Tourism and Hospitality Research, 8(4), 401-419 https://doi.org/10.1108/IJCTHR-04-2014-0032.

Cortada, D. M. (2006). El diálogo turismo y cultura. Revista Pensar Iberoamerica, 1683-3783. ISSN-e. Retrieved 29 February 2019 from https://dialnet.unirioja.es/ servlet/articulo? codigo $=1700765$.

Crompton, J. (1979). Motivations for pleasure vacation. Annals of Tourism Research, 6(4), 408-424. https://doi.org/10.1016/0160-7383(79)90004-5.

Csapó, J. (2012). The role and importance of cultural tourism in modern tourism industry In M. Kasimoglu (Ed.). Strategies for tourism industry - Micro and macro perspectives (pp. 201-232). London: InTech.

Dash, M., Liu, H., Scheuermann, P., \& Tan, K. L. (2003). Fast hierarchical clustering and its validation. Data \& Knowledge Engineering, 44(1), 109-138. https://doi.org/10. 1016/S0169-023X(02)00138-6.

Dekker, T., \& Tabbers, M. (2012). From creative crowds to creative tourism: A search for creative tourism in small and medium sized cities. Journal of Tourism Consumption and Practice, 4(2), 129-141.

Dolnicar, S., \& Grün, B. (2008). Challenging "factor-cluster segmentation". Journal of Travel Research, 47(1), 63-71. https://doi.org/10.1177/0047287508318910.

Duxbury, N. (2020). Catalyzing creative tourism in small cities and rural areas in Portugal: The CREATOUR approach. In K. Scherf (Ed.). Creative tourism in smaller communities: Place, culture, and local representation. Calgary, AB: University of Calgary Press.

Duxbury, N., \& Richards, G. (2019a). Towards a research agenda for creative tourism: Developments, diversity, and dynamics. In N. Duxbury, \& G. Richards (Eds.). A research agenda for creative tourism (pp. 1-14). Cheltenham: Edward Elgar Publishing.

Duxbury, N., \& Richards, G. (2019b). Towards a research agenda for creative tourism: A synthesis of suggested future research trajectories. In N. Duxbury, \& G. Richards (Eds.). A research agenda for creative tourism (pp. 182-192). Cheltenham: Edward Elgar Publishing.

Egger, R., Gula, I., \& Walcher, D. (2016). Towards a holistic framework of open tourism. In R. Egger, I. Gula, \& D. Walcher (Eds.). Open tourism: Open innovation, crowdsourcing and co-creation challenging the tourism industry (pp. 3-16). Berlin: Springer. https:// doi.org/10.1007/978-3-642-54089-9 1.

Florida, R. (2002). The rise of the creative class: And how it's transforming work, leisure, community and everyday life. New York: Basic Books.

Gonçalves, A. R., Borges, R., Duxbury, N., Carvalho, C. P., \& Costa, P. (2020). Policy recommendations on creative tourism development in small cities and rural areas. Coimbra: CREATOUR project, Centre for Social Studies, University of Coimbra.

Gordin, V., \& Matetskaya, M. (2012). Creative tourism in Saint Petersburg: The state of the art. Journal of Tourism Consumption and Practice, 4(2), 55-77.

Guerreiro, A., \& Marques, J. F. (2017). Visita guiada à Fábrica de Antiguidades: Sociologia, turismo e autenticidade. Anais Brasileiros de Estudos Turísticos, 7(1), 8-22. https://doi.org/10.34019/2238-2925.2017.v7.3160.

Hair, J., Black, W., Babin, B., Anderson, R., \& Tatham, R. (2010). Multivariate data analysis (7th ed.). London: Prentice Hall.

Huang, Y. C., Chang, L. L., \& Backman, K. F. (2019). Detecting common method bias in predicting creative tourists' behavioural intention with an illustration of theory of planned behaviour. Current Issues in Tourism, 22(3), 307-329 10.1080/ 13683500.2018.1424809.

Hung, W. L., Lee, Y. J., \& Huang, P. H. (2016). Creative experiences, memorability and revisit intention in creative tourism. Current Issues in Tourism, 19(8), 763-770. https://doi.org/10.1080/13683500.2013.877422.

Ilincic, M. (2014). Benefits of creative tourism-The tourist perspective. Expert Meeting on Alternative and Creative Tourism in Cities (pp. 99-113). Chapter 9. (13-14 June 2013, Barcelona).

Jelinčić, D., \& Žuvela, M. (2012). Facing the challenge? Creative tourism in Croatia. Journal of Tourism Consumption and Practice, 4(2), 79-98.

Kajzar, P. (2013). Greece as cultural destination. 16th international colloquium on regional sciences (pp. 636-642). Brno: Masarykovauniverzita. https://doi.org/10.5817/CZ. MUNI.P210-6257-2013-80.

Kajzar, P. (2014). Cultural tourism and world heritage. Hustopeče, 18, 901-906. https:// doi.org/10.5817/CZ.MUNI.P210-6840-2014-117.

King, B. (2009). Creative tourism and cultural development: Some trends and observations. Paper presented at the Cultural Tourism Conference, Bonavista Institute for Cultural Tourism, Newfoundland, Canada, 19 November.

Kotler, P., Kartajaya, H., Setiawan, I., \& Vandercammen, M. (2012). Marketing 3.0: Produits, clients, facteurshumains. Bruxelles: Edition de Boeck.

Maisel, E. (2009). Bridging the artist-tourist gap. In R. Wurzburger, T. Aegeson, A. Pattakos, \& S. Pratt (Eds.). Creative tourism: A global conversation (pp. 171-182). Santa Fe: Sunstone Press.

Mazanec, J. A. (2000). Market segmentation. In J. Jafari (Ed.). Encyclopedia of tourism (pp. 374-375). London: Routledge.

McKercher, B., Ho, P., du Cros, H., \& Chow, B. (2002). Activities-based segmentation of the cultural tourism market. Journal of Travel \& Tourism Marketing, 12(1), 23-46 https://doi.org/10.1300/J073v12n01 02.

Melo, C., Correia, A., Cardoso, M., \& Marques, V. (2019). Creative tourism experiences in Guimarães: A twofold analysis of visitors' and suppliers' perspectives. Revista Portuguesa de Estudos Regionais, 51, 73-91.
Mihajlović, I., \& Koncul, N. (2016). Changes in consumer behaviour - the challenges for providers of tourist services in the destination. Economic ResearchEkonomskaIstraŽivanja, 29(1), 914-937. https://doi.org/10.1080/1331677X.2016. 1206683.

Moscardo, G. (1996). Mindful visitors: Heritage and tourism. Annals of Tourism Research, 23(2), 376-397. https://doi.org/10.1016/0160-7383(95)00068-2.

Mota, M., Remoaldo, P. C., \& Ribeiro, J. C. (2012). Criatividade: a construção de novos cenários para o turismo em Ponte de Lima. Revista Portuguesa de Estudos Regionais, 29(1), 59-70. Retrieved 29 January 2019 from: http://www.apdr.pt/siterper/ numeros/RPER29/29.6.pdf.

Mousavi, S., Doratli, N., Mousavi, S., \& Moradiahari, F. (2016). Defining cultural tourism. International conference on civil, architecture and sustainable development (CASD-2016) (pp. 70-75). UK: London.

Network, C. T. (2018). Creative tourism magazine. Retrieved 28 February 2019 from: https://issuu.com/creativetourismnetwork/docs/magazine_creative_tourism_ network.

O'Dell, T. (2007). Tourist experiences and academic junctures. Scandinavian Journal of Hospitality and Tourism, 7(1), 34-45. https://doi.org/10.1080/15022250701224001.

Ohridska-Olson, R. V., \& Ivanov, S. H. (2010). Creative tourism business model and its application in Bulgaria. Proceedings of the Black Sea tourism forum "Cultural tourism-The future of Bulgaria" (pp. 1-17). .

Pappalepore, I., Maitland, R., \& Smith, A. (2014). Prosuming creative urban areas: Evidence from East London. Annals of Tourism Research, 44, 227-240. https://doi. org/10.1016/j.annals.2013.11.001.

Pearce, D., \& Butler, R. (1993). Tourism research—Critiques and challenges. London: Routledge.

Peters, M., Frehse, J., \& Buhalis, D. (2009). The importance of lifestyle entrepreneurship: A conceptual study of the tourism industry. PASOS: Revista de Turismo y Patrimonio Cultural, 7(2), 393-405.

Pine, B., \& Gilmore, J. (1999). Welcome to the experience economy. Harvard Business Review, 76(4), 97-105.

Prahalad, C., \& Ramaswamy, V. (2004). The future of competition: Co-creating unique value with customers. Boston: Harvard Business School Press.

Prentice, R., \& Andersen, V. (2007). Creative tourism supply: Creating culturally empathetic destinations. In G. Richards, \& J. Wilson (Eds.). Tourism, creativity and development (pp. 89-107). London: Routledge.

Puczkó, L. (2013). Visitor experiences in cultural spaces. In M. Smith, \& G. Richards (Eds.). Routledge handbook of cultural tourism (pp. 389-395). London: Routledge.

Ray, P. H., \& Anderson, S. (2000). The cultural creatives: How 50 million people are changing the world (illustrated ed.). New York: Harmony Books.

Raymond, C. (2003). Cultural renewal + tourism: Case study-Creative tourism. New Zealand. Retrieved 29 January 2019 from: http://www.creativenz.govt.nz/assets/ paperclip/publication_documents/documents/97/original/casestudy-creativetourism-new-zealand.pdf?1322079829.

Raymond, C. (2007). Creative tourism New Zealand: The practical challenges of developing creative tourism. In G. Richards, \& J. Wilson (Eds.). Tourism, creativity and development (pp. 145-157). London: Routledge.

Reis, E. (2001). Estatística multivariada aplicada (2nd ed.). Lisbon: Sílabo.

Remoaldo, P., \& Ribeiro, J. C. (2017). O legado de guimarães capital Europeia da cultura de 2012. A leitura dos residentes e dos visitantes. Porto: Edições Afrontamento.

Remoaldo, P., Matos, O., Freitas, I., Lopes, H., Ribeiro, V., Gôja, R., \& Pereira, M. (2019). Good and not-so-good practices in creative tourism networks and platforms: An international review. In N. Duxbury, \& G. Richards (Eds.). A research agenda for creative tourism (pp. 167-181). London: Edward Elgar Publishing.

Remoaldo, P., Matos, O., Gôja, R., Alves, J., \& Duxbury, N. (2020). Management practices in creative tourism: Narratives by managers from international institutions to a more sustainable form of tourism. Geosciences, 10(2), 1-12. https://doi.org/10.3390/ geosciences10020046.

Remoaldo, P., Vareiro, L., \& Ribeiro, J. C. (2017). Changes in the Guimarães visitors' profile and the city attributes perceptions in the post hosting of the 2012 European Capital of Culture. Tourism \& Management Studies, 13(4), 43-53.

Ribeiro, V., Remoaldo, P., Pereira, M., Gôja, R., Matos, O., Freitas, I., \& Alves, J. (2020) Geo-crowdsourcing contributions for cultural mapping. Journal of Information Science Theory and Practice, 8(1), 56-67. https://doi.org/10.1633/JISTaP.2020.8.1.5.

Richards, G. (2003). Cultural tourism research methods. Amsterdam: Great Britain by TJ International.

Richards, G. (2010a). Creative tourism and local development. In R. Wurzburger, A. Pattakos, \& S. Pratt (Eds.). Creative tourism: A global conversation (pp. 78-90). Santa Fe: Sunstone Press.

Richards, G. (2010b). Tourism development trajectories: From culture to creativity? Tourism \& Management Studies, 6, 9-15.

Richards, G. (2011). Creativity and tourism: The state of the art. Annals of Tourism Research, 38(4), 1225-1253. https://doi.org/10.1016/j.annals.2011.07.008.

Richards, G. (2014a). Creativity and tourism in the city. Current Issues in Tourism, 17(2), 119-144. https://doi.org/10.1080/13683500.2013.783794.

Richards, G. (2014b). Development of experiences in creative tourism. In C. E. Ong (Coord.), Experiences \& environments. Lecture conducted at Wageningen University, The Netherlands.

Richards, G., \& Raymond, C. (2000). Creative tourism. ATLAS News, 23, 16-20.

Richards, G., \& Wilson, J. (2006). Developing creativity in tourist experiences: A solution to the serial reproduction of culture? Tourism Management, 27, 1209-1223. https:// doi.org/10.1016/j.tourman.2005.06.002.

Richards, G., \& Wilson, J. (2007). Tourism, creativity and development. London: Routledge.

Rudan, E. (2012). Razvojne perspective kretivnoga turizma Hrvatske. Ekonomska misao $i$ praksa, 21(2), 713-730.

Ryan, C., \& Glendon, I. (1998). Application of leisure motivation scale to tourism. Annals 
of Tourism Research, 25(1), 169-184. https://doi.org/10.1016/S0160-7383(97) 00066-2.

de Serralves, F. (2008). Estudo macroeconómico desenvolvimento de um cluster de indústrias criativas na região do Norte. Portugal: Fundação de Serralves.

Silberberg, T. (1995). Cultural tourism and business opportunities for museums and heritage sites. Tourism Management, 16(5), 361-365.

Smith, M. (2003). Issues in cultural tourism studies. London: Routledge.

Smith, M. (2016). Issues in cultural tourism studies (3rd ed.). New York: Routledge.

Stolarick, K., Denstedt, M., Donald, B., \& Spencer, G. (2010). Creativity, tourism and economic development in a rural context: The case of Prince Edward County. Journal of Rural and Community Development, 5, 238-254.

Tan, S. K., Kun, S. F., \& Luh, D. B. (2013). A model of creative experience in creative tourism. Annals of Tourism Research, 41, 153-174. https://doi.org/10.1016/j.annals. 2012.12.002.

Tan, S. K., Luh, D. B., \& Kung, S. F. (2014). A taxonomy of creative tourists in creative tourism. Tourism Management, 42, 248-259. https://doi.org/10.1016/j.tourman. 2013.11.008.

Toffler, A. (1980). The third wave. New York: Bantam Books.

Virginija, J. (2016). Interaction between cultural/creative tourism and tourism/cultural heritage industries. In L. Butowski (Ed.). Tourism - from empirical research towards practical application (pp. 137-156). Rijeka: InTech.

Williams, A. M. (2010). Mass tourism, culture and the historic city: Theoretical perspectives. Rivista di Scienze del Turismo, 2, 9-29.

Zhang, Y., \& Yu, X. (2018). Urban tourism and the politic of creative class: A study of the chefs in Macao. International Journal of Tourism Sciences, 18(2), 139-151. https://doi. org/10.1080/15980634.2018.1471880.

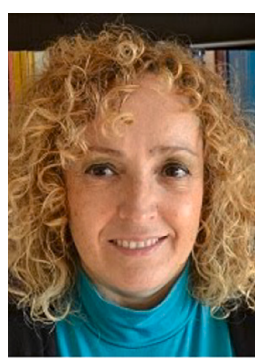

Paula Cristina Almeida Cadima Remoaldo (http://orcid. org/0000-0002-9445-5465), is a Full Professor in the Department of Geography of the Social Sciences Institute, University of Minho, Portugal. She is the Head of Lab2PT (Landscape, Heritage and Territory Laboratory - since 2017) and the leader of Tourism and Development group in this Laboratory. Her main subjects of research are in the area of Cultural Tourism and Regional and Local Development.

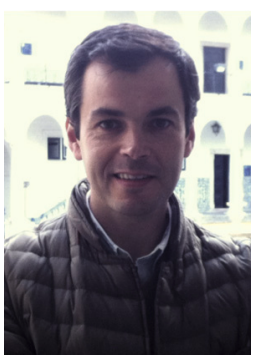

Jaime Serra (https://orcid.org/0000-0002-0299-4649), Assistant Professor of the School of Social Sciences at the University of Évora in the field of Tourism Studies (Bachelor and Master degrees). He is also researcher at the Interdisciplinary Centre for History, Culture and Societies (CIDEHUS) - University of Évora. His research interests are in the field of tourism demand trends; tourist behaviour; tourism and demography; applied quantitative methods. Coordinator of the CREATIVE TOURISM LAB at CIDEHUS.

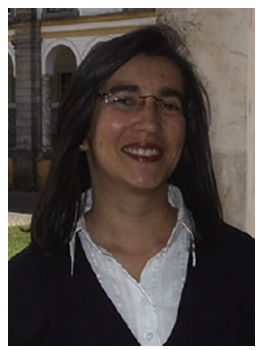

Noémi Marujo (https://orcid org/0000-0001-8058-5130) Assistant Professor of the School of Social Sciences at University of Évora in the field of tourism studies. She is also research at the Interdisciplinary Centre for History, Culture and Societies (CIDEHUS). Scientific Council Member of CIDEHUS. Member of the UNESCO Chair Team in "Intangible Heritage and Traditional KnowHow: Linking Heritage" (University of Évora - Portugal).

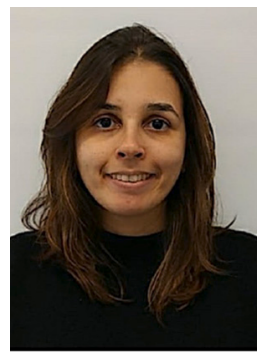

Juliana Araújo Alves (https://orcid.org/0000-0002-9520 7017) is investigator at Lab2PT (Landscape, Heritage and Territory Laboratory). She holds a PhD in Human Geography from University of Minho, Portugal. She also has a post-doctorate from University of Minho in the field of Creative Tourism. Her main subjects of research are in the area of Creative Tourism and Sustainable Management, and Local and Regional Development.

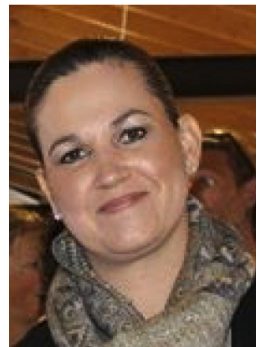

Alexandra Gonçalves (https://orcid.org/0000-0003 3796-1801) is an Integrated Researcher at CinTurs (Research Center on Tourism, Sustainability and Wellbeing) and Adjunct Professor of the School of Management, Tourism and Hospitality from the University of the Algarve.

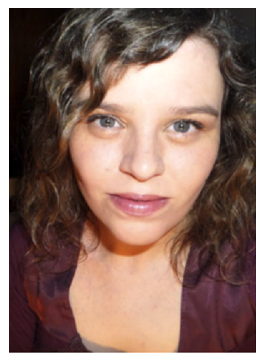

Sónia Cabeça (https://orcid.org/0000-0003-4667-2788) is an integrated researcher at CinTurs (Research Center on Tourism, Sustainability and Wellbeing) and researcher at the UNESCO chair in Intangible Heritage and Traditional Know-How: Linking Heritage. Specialist in Ethnossociology and Intangible Heritage, devoted sev eral years to the study of Cante Alentejano, a traditional chant from Alentejo, and its bearers.

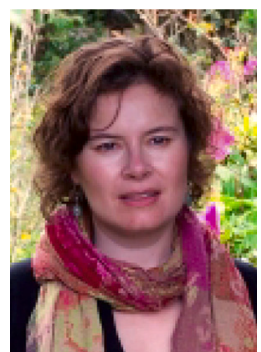

Nancy Duxbury (https://orcid org/0000-0002-5611-466X) is a Senior Researcher at the Centre for Social Studies, University of Coimbra, Portugal, and Co-coordinator of its Cities, Cultures and Architecture Research Group. She is an Adjunct Professor of the School of Communication, Simon Fraser University, Vancouver, Canada, and the School of Urban and Regional Planning, University of Waterloo, Canada. 